concentrations. In less acute infections metronidazole is indicated because of its high bactericidal activity at concentrations attained in the blood (Nastro and Finegold, 1972; Whelan and Hale, 1973). Rifampicin though having a high degree of activity against bacteroides should probably be reserved for the treatment of tuberculosis. The activity of fusidic acid suggests that it may be effective in the local treatment of bacteroides infections.

The incidence of bacteroides in postoperative wound infections was significantly high and the increase over the study period to $81 \%$ was startling. The reasons for this increase are twofoldfirstly, a greater awareness on the part of the surgeons to send operative samples from patients found to have infection at abdominal surgery, and, secondly, improvements in laboratory techniques and transportation of specimens throughout the hospital. A smaller increase in the isolation of all anaerobic bacteria with improved cultural methods has also been reported by Hoffman and Gierhake (1969).

Bacteroides infections, especially of postoperative wounds, appear to be largely preventable by antibiotic therapy. It is essential to obtain samples for bacteriological examination at the time of surgery. Early diagnosis of bacteroides infections will lead to appropriate antibiotic therapy being given and it is likely that many postoperative wound infections would be prevented. Clindamycin or lincomycin should always be included in the primary treatment of all suspected abdominal infections.

I should like to thank the technicians of the microbiology laboratory for their diligenœ in the isolation of bacteroides, Mrs. K. Simmons for determining the antibiatic sensitivities, and Mrs. E. Norman, control of infection sister, who was responsible for the wound infection survey.

Mrs. K. Simmons is in receipt of a research grant from Beecham Research Laboratories.

\section{References}

Bartlett, J.G., Sutter, V. L., and Finegold, S. M. (1972). New England fournal of Medicine, 287,1006 .

Bodner, S. J., Koenig, M. G., and Goodman, J. S. (1970). Annals of Internal Medicine, 73, 537 .

Bodner, S. J., et al. (1972). Antimicrobial Agents and Chemotherapy, 2, 57.

Collee, J. G., et al. (1972). Fournal of Applied Bacteriology, 35, 71 . Cowan, S. T., and Steel, K. J. (1965). Manual for the Idom

Ellner, P. D., and Wasilauskas, B. L. (1971). Fournal of the American Geriatric Society, 19, 296.

Felner, J. M., and Dowell, V. R. (1971). American fournal of Medicine, 60, 787.

Gelb, A. F., and Seligman, S. J. (1970). Fournal of the American Medical Association, 212, 1038 .

Gillespie, W. A., and Guy, J. (1956). Lancet, 1, 1039.

Gunn, A. A. (1956). fournal of the Royal College of Surgeons of Edinburgh, $2,41$.

Halle, J. (1898). Quoted by Gillespie, and Guy (1956).

Hoffman, K., and Gierhake, F. W. (1969). German Medical Monthly, 14, 31.

Kagnoff, M. F., Armstrong, D., and Blevins, A. (1972). Cancer (Philadelphia), 29,245 .

Kislak, J. W. (1972). Journal of Infectious Diseases, 125, 295.

Ledger, W. J. (1972). Surgical Clinics of North America, 52, 1447.

Ledger, W. J., Sweet, R. L., and Headington, J. T. (1971). Surgery, Gynecology and Obstetrics, 133, 837

Martin, W. J., Gardner, M., and Washington, J. A. (1972). Antimicrobial Agents and Chemotherapy, 1, 148. Mitchell, A. A. B., and Simpson, R. G. (1973). Current Medical Research
and Opinion, i, 385 .

Nastro, L. J., and Finegold, S. M. (1972). Fournal of Infectious Diseases, 126, 104.

Okubadejo, O. A., Green, P. J., and Payne, D. J. H. (1973). British Medical fournal, 2,212 .

Pasteur, L. (1863). Quoted by Gunn (1956).

Pearson, H. E., and Anderson, G. V. (1970). Obstetrics and Gynecology, 35, 31.

Sinkovics, J. G., and Smith, J. P. (1970). Cancer (Philadelphia), 25, 663.

Stokes, E. J. (1958). Lancet, 1, 668.

Tracy, O., et al. (1972). British Medical fournal, 1, 280.

Veillon, A., and Zuber, A. (1898). Archives de Médecine Expérimentale et d'Anatomie Pathologique, 10, 517.

Vincent, H. (1896). Annales de l'Institut Pasteur, 10, 488.

Whelan, J. P. F., and Hale, J. H. (1973). Journal of Clinical Pathology, 26,

Wilson, W. R., et al. (1972). Mayo Clinic Proceedings, 47, 639.

\title{
Influence of Previous Oral Contraception and Maternal Oxytocin Infusion on Neonatal Jaundice
}

\author{
S. R. GOULD, U. MOUNTROSE, \\ D. J. BROWN, \\ W. L. WHITEHOUSE, \\ D. E. BARNARDO
}

British Medical fournal, 1974, 3, 228-230

Wood, 1971; McConnell et al., 1973). One of us, however, failed to confirm this association in a preliminary survey (Barnardo et al., 1972). Wong and Wood (1971) related the increased incidence of jaundice to breast-feeding as well as to previous maternal oral contraception. By contrast, McConnell et al. (1973) related this to bottle-feeding and not to breastfeeding. The maternal infusion of oxytocic agents such as syntocinon has also been implicated as a cause of neonatal jaundice by some workers (Ghosh and Hudson, 1972; Davies et al., 1973), though this has not been found by others (McConnell et al., 1973).

In 181 mothers and neonates we have prospectively studied the relation between maternal and neonatal serum bilirubin levels, maternal oral contraceptive history, maternal exposure to oxytocic agents immediately preceding delivery, and the method of feeding in the first six days of life.

An increased incidence of neonatal jaundice has been noted in babies born to mothers who used oral contraceptives (Wong and

Queen Mary's Hospital, Roehampton, London S.W.15

S. R. GOULD, B.SC., M.R.C.P., Medical Registrar (Present address: Westminster Hospital, London SW 1P 2AP)

U. MOUNTROSE, M.B., M.R.C.O.G., Obstetric Registrar

W. L. WHITEHOUSE, F.R.c.S., F.R.C.O.G., Consultant Obstetrician and Gynaecologist

D. E. BARNARDO, M.D., M.R.C.P., Consultant Physician

Medical Computer Centre, Westminster Hospital, London SW1P 2AP D. J. BROWN, M.A., B.SC., Statistician

\section{Methods}

Consecutive single-birth deliveries in the obstetric unit, Queen Mary's Hospital, Roehampton, during a two-month period in mid-1973 were included in the study. Out of 209 mothers and neonates 28 were excluded for the following reasons: no bilirubin data (8), mixed feeding in the first six days of life (6), no information on previous oral contraception (5), neonatal 
illness (5), prematurity (birth weight $<2,500 \mathrm{~g}$ ) (2), and rhesus haemolytic disease (2).

Inquiry was made about previous maternal oral contraception. The duration of use was not recorded as recall was found to be unreliable but date of discontinuance was noted.

Oxytocin (Syntocinon) was given intravenously to 100 of the mothers as a routine measure to expedite delivery. The duration of infusion was recorded but more quantitative data were unavailable as rates of infusion were not always recorded.

Epidural anaesthesia with bupivacaine was used in 109 of the mothers at the time of delivery.

Neonatal serum bilirubin was measured in cord blood taken at birth and in blood taken routinely on the sixth day of life for amino-acid screening. Maternal blood was also taken at the time of delivery. The serum bilirubin was measured by the method of Michaëlsson et al. (1965). Samples were stored in the dark at $4^{\circ} \mathrm{C}$ and analysed within 24 hours of collection.

Comparisons of mean values among more than two groups were made using the Kruskal-Wallis analysis of variance H statistic (Siegal, 1956) rather than the F test (which requires the assumptions of normality and equal variance in the groups) in order to increase the generality of any significant results with minimal loss of efficiency. Comparisons between pairs of groups were made using Student's $t$ test.

\section{Results}

No differences were found between the neonatal serum bilirubin levels on day $1(P>0.8)$ or day $6(P>0.7)$ in babies grouped according to history of previous maternal oral contraception and method of feeding (table I). The serum bilirubin levels of babies born to mothers who had stopped taking oral contraceptives three months or less before conception were compared with those of babies whose mothers had stopped oral contraceptives more than three months before conception. No significant differences were apparent between these two groups or between babies whose mothers had recently discontinued oral contraception and those whose mothers had not used oral contraceptives at all.

TABLE I-Mean Serum Bilirubin Levels $(\mathrm{mg} / 100 \mathrm{ml}$ ) of Neonates grouped according to Maternal Contraceptive (Pill) History and Method of Feeding (Breast or Bottle)

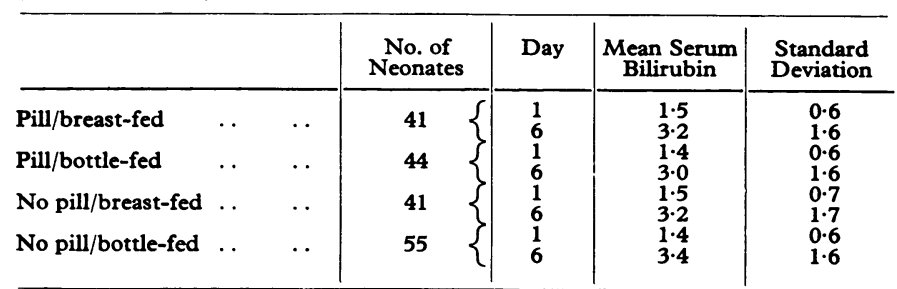

Day $1(\mathrm{H}=0.724, \mathrm{P}>0.8)$ : no significant difference between the four groups.

Day $6(H=1.188, P>0.7)$ : no significant difference between the four groups.

The use of oxytocin during labour was not found to influence the neonatal serum bilirubin level (table II). The oxytocin/no oxytocin groups were comparable in the distribution of breastfeeding and bottle-feeding ( $\chi^{2}$ test, $\left.P=0.99\right)$ and mean birth weights $(t=1 \cdot 103, P=0 \cdot 27)$. In babies whose mothers had received oxytocin there was no correlation between serum bilirubin level and duration of infusion (day $1, r=0 \cdot 10$, N.S.; day $6, \mathrm{r}=0 \cdot 13$, N.S.).

Epidural anaesthesia had no effect on neonatal serum bilirubin levels on day 1 or day 6 or on the serum bilirubin levels of the 109 mothers who received the epidural anaesthetic compared with those who did not. The two groups did not differ significantly in the babies' mean birth weights or in the distribution of breast-feeding and bottle-feeding.

There was no difference in serum bilirubin level between breast-fed and bottle-fed infants. The mean level on day 6 of
82 breast-fed neonates was $3.2 \mathrm{mg} / 100 \mathrm{ml}$, and this was identical with that of the 99 bottle-fed neonates. Nor did the mean birth weights of the two groups differ significantly $(t=1 \cdot 455$, $(\mathbf{P}=0 \cdot 16)$.

Breast-fed babies born to mothers previously taking oral contraceptives were slightly but significantly heavier (by about $250 \mathrm{~g})(\mathrm{P}<0.02)$ (table III).

TABLE II-Mean Serum Bilirubin Levels $(\mathrm{mg} / 100 \mathrm{ml})$ of Neonates grouped according to Maternal Oxytocin Infusion

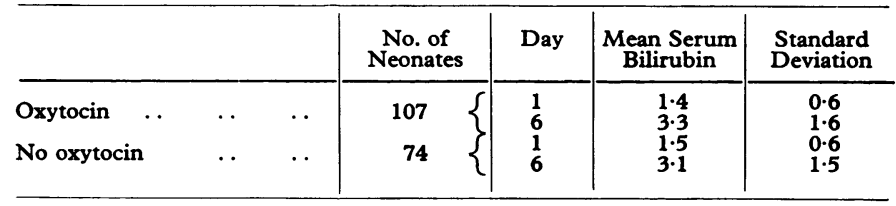

Day $1(t=1 \cdot 012, \mathrm{P}=0 \cdot 26)$ : no significant difference between groups. Day $6(t=0.648, P=0.51)$ : no significant difference between groups.

TABLE III-Birth Weights $(g)$ of Neonates grouped according to Maternal Contraceptive (Pill) History and Method of Feeding (Breast or Bottle)

\begin{tabular}{|c|c|c|c|c|c|}
\hline & & & $\begin{array}{c}\text { No. of } \\
\text { Neonates }\end{array}$ & $\begin{array}{c}\text { Mean } \\
\text { Birth Weight }\end{array}$ & $\begin{array}{l}\text { Standard } \\
\text { Deviation }\end{array}$ \\
\hline $\begin{array}{l}\text { Pill/breast-fed .. } \\
\text { Pill/bottle-fed . } \\
\text { No pill/breast-fed } \\
\text { No pill/bottle-fed }\end{array}$ & $\begin{array}{l}\ldots \\
\ldots \\
\ldots\end{array}$ & $\begin{array}{l}\ldots \\
\cdots \\
\cdots\end{array}$ & $\begin{array}{l}41 \\
44 \\
41 \\
55\end{array}$ & $\begin{array}{l}3,530 \\
3,270 \\
3,260 \\
3,320\end{array}$ & $\begin{array}{l}4 \cdot 30 \\
4 \cdot 20 \\
3 \cdot 80 \\
4 \cdot 60\end{array}$ \\
\hline
\end{tabular}

Pill/breast-fed group was significantly heavier $(P<0.02)$.

\section{Discussion}

The Michaëlsson method for the estimation of unconjugated serum bilirubin is the most reliable available (Billing et al., 1971). It is preferable to other methods because of its greater accuracy with low readings and lack of interference from haemoglobin in haemolysed samples.

There is no evidence from our data that previous oral contraception influences the serum bilirubin at either the first or sixth day of life. Even within the group of mothers who stopped oral contraceptives three months or less before conception there was no detectable influence. This is in agreement with the data of Barnardo et al. (1972).

Though peak neonatal serum bilirubin levels might not be expected until two or three days after birth it is reasonable to expect that prenatal factors would influence the level on the first and sixth days also. These were times when biochemical analysis could be made without subjecting the babies to extra blood taking.

The study of McConnell et al. (1973) in Belfast showed an icterogenic effect of both prior oral contraception and breastfeeding. The scatter of serum bilirubin levels within each of their groups appeared considerable and was greater than in our series. This may be due to an intrinsic difference between the populations studied as suggested by the low incidence of breastfeeding ( $8 \%$ ). In our series $45 \%$ of the babies were breast-fed. No comment was made regarding the birth weights of the compared groups and this could be a factor in influencing differences in bilirubin concentrations.

The absence of demonstrable effect of maternal oxytocin infusion on neonatal serum bilirubin levels on the first and sixth days is contrary to the findings of Ghosh and Hudson (1972) and Davies et al. (1973) but is in agreement with the results of McConnell et al. (1973).

Finally, there is no support for the contention (Arthur et al., 1966) that there is a tendency towards higher serum bilirubin levels on the sixth day of life in breast-fed compared with bottle-fed babies.

We thank Mrs. Pam Herrick for invaluable technical help with the serum bilirubin determinations; Professor P. Curzen and $\mathrm{Mr}$. 
H. Roberts for permission to study patients under their care; and Miss R. Menheneott and Miss Y. White for secretarial work.

Requests for reprints should be addressed to Dr. D. E. Barnardo.

\section{References}

Arthur, L. J. H., Bevon, B. R., and Holton, J. B. (1966). Developmental Medicine and Child Neurology, 8, 279.
Barnardo, D. E., Stothers, I., and Sharratt, M. (1972). British Medical fournal, 2,348 .

Billing, B., Haglam, R., and Wald, N. (1971). Annals of Clinical Biochemistry, $8,21$.

Davies, D. P., et al. (1973). British Medical fournal, 3, 476.

Ghosh, A., and Hudson, F. P. (1972). Lancet, 2, 823 .

McConnell, J. B., Glasgow, J. F. T., and McNair, R. (1973). British Medical Fournal, 2, 605.

Michaëlsson, M., Nosslin, B., and Siölin, S. (1965). Pediatrics, 35, 925.

Siegal, S. (1956). Nonparametric Statistics. New York, McGraw-Hill.

Wong, Y. K., and Wood, B. S. B. (1971). British Medical fournal, 4, 403.

\title{
Influence of Smoking on Deep Vein Thrombosis after Myocardial Infarction
}

\author{
ANTHONY J. HANDLEY， DEREK TEATHER
}

British Medical fournal, 1974, 3, 230-231

\section{Summary}

As part of a study of the factors affecting the risk of deep vein thrombosis after myocardial infarction a surprising and unexplained finding was that non-smokers had a significantly higher incidence of thrombosis than cigarette smokers.

\section{Introduction}

Deep vein thrombosis, as detected by the radioactive fibrinogen test (Kakkar et al., 1970), occurs in about $35 \%$ of patients after myocardial infarction (Murray et al., 1970). The incidence is higher in older patients and those with varicose veins (Maurer et al., 1971) and in the more severely ill (Nicolaides et al., 1971). We report here the results of a prospective study of the factors affecting the risk of leg vein thrombosis after myocardial infarction.

\section{Patients and Methods}

The patients studied were those entering the coronary care unit of Queen Mary's Hospital, Roehampton, with a clinical diagnosis of myocardial infarction. About half constituted the control groups of two studies of prophylactic heparin therapy (Handley et al., 1972; Handley, 1972), the remainder being consecutive admissions to the unit. The patients received an intravenous injection of ${ }^{125}$ I-fibrinogen within 18 hours of admission to hospital, and a scintillation counter was used to examine their legs for the presence of deep vein thrombosis on alternate days for at least two weeks, using the technique described by Kakkar et al. (1970). Anticoagulants were not given unless there was ${ }^{125}$ I-fibrinogen evidence of deep vein thrombosis.

Each patient was questioned about previous episodes of venous thromboembolism and examined for the presence of

Queen Mary's Hospital, Roehampton, London SW15

ANTHONY J. HANDLEY, M.B., M.R.C.P., Senior Medical Registrar (Present address: Brompton Hospital, London SW3 6HP) Department of Statistics, University College, London

DEREK TEATHER, M.sC., Research Associate varicose veins. The severity of the myocardial infarct was assessed by means of the Peel index (Peel et al., 1962). Smoking habits were recorded using the following definitions: (a) regular smoking-one or more cigarettes a day for at least the past year, with continued smoking up to the month before admission; (b) previous smoking-one or more cigarettes a day for at least a year in the past but none for at least a month before admission; (c) non-smoking-less than one cigarette a day for any year in the past.

\section{Results}

A total of 160 patients were studied. Of these, 45 were excluded because the clinical diagnosis of myocardial infarction was not confirmed by electrocardiographic or serum enzyme changes. Eight patients died within the two-week follow-up period. One had evidence of deep vein thrombosis at the time and necropsy confirmed the cause of death as massive pulmonary embolus; this patient was a non-smoker. A further seven patients were withdrawn from the study before the end of two weeks either because they were given anticoagulants by the clinician in charge of the case or because they were discharged from hospital; none had any evidence of deep vein thrombosis at the time. The remaining 100 patients all completed two weeks of follow-up, at which time the study was concluded. Comparison of the characteristics of the patients who were withdrawn with those of the patients who were studied showed no significant differences (table I).

Patients aged 70 years and over had a significantly higher incidence of deep vein thrombosis than those between 50 and 69 years of age $(P<0.001)$ (table II). The incidence in men $(37 \%)$ was similar to that in women $(33 \%)$.

TABLE I-Comparison of Patients Included in Study with Those Withdrawn for Reasons Given

\begin{tabular}{l|c|c|c|c}
\hline & $\begin{array}{c}\text { No. of } \\
\text { Patients }\end{array}$ & $\begin{array}{c}\text { Mean Age } \\
\text { (Years) }\end{array}$ & $\begin{array}{c}\text { Males: } \\
\text { Females }\end{array}$ & $\begin{array}{c}\text { Smokers: } \\
\text { Non-smokers }\end{array}$ \\
\hline $\begin{array}{l}\text { Death } \\
\begin{array}{l}\text { Anticoagulated, or } \\
\text { discharged }\end{array}\end{array}$ & 7 & $\begin{array}{c}64 \cdot 8 \\
56 \cdot 0\end{array}$ & $\begin{array}{c}5: 3 \\
6: 1\end{array}$ & $\begin{array}{c}5: 3 \\
5: 2\end{array}$ \\
\hline Total withdrawals & 15 & $60 \cdot 6$ & $\begin{array}{c}11: 4 \\
(2 \cdot 8: 1)\end{array}$ & $\begin{array}{c}10: 5 \\
(2: 1)\end{array}$ \\
\hline Group studied & 100 & $61 \cdot 6$ & $\begin{array}{c}73: 27 \\
(2 \cdot 7: 1)\end{array}$ & $\begin{array}{c}61: 37^{*} \\
(1 \cdot 6: 1)\end{array}$ \\
\hline
\end{tabular}

-Incomplete clinical information on two patients. 